the Institute for Limnology. Prof. Kühn has lost all his close collaborators and is training young workers. His main interest at present is the chemical action of genes; in this work he is collaborating with Prof. Butenandt, who occupies the chair of physiological chemistry in Tübingen.

\section{Study of Photo-elasticity}

IT has been suggested that a society or association should be formed in Great Britain for men of science and engineers who are interested in the development and applications of photo-elasticity. Such an organisation would enable research workers in this field to keep in touch with each other and, in particular, would provide a common meeting ground for workers in industrial, government and university laboratories. Messrs. H. T. Jessop (Engineering Department, University College, Gower Street, London, W.C.1) and F. K. Frankl (Cambridge University Engineering Department, Trumpington Street, Cambridge) state that it is proposed to arrange a meeting on September 6 at 11 a.m. at University College, London, at which the general character and aims of such a society could be discussed. Communications about the meeting should be sent to Mr. Frankl at the address given above.

\section{Association of Special Libraries and Information Bureaux: Annual Conference}

THE twenty-first conference of the Association of Special Libraries and Information Bureaux will be held at the Polytechnic, Regent Street, London, W.1, during September 13-15, and a provisional programme has been issued. The presidential address, by Sir Reginald Stradling, will be given on September 14, and the subject is "Special Libraries in Research Organisations". Papers have been promised on the preparation of critical bibliographies (A. D. Roberts, British Library of Political and Economic Science), communication of specialist information to business executives (Prof. R. S. Hutton), mathematical machines and tables (Dr. L. J. Comrie, Scientific Computing Service, Ltd.), and technical dictionaries and glossaries (Miss M. Gosset, Science Library). A symposium on aspects of documentation in Europe has been arranged for September 15 (morning session), at which Mrs. Lancaster-Jones (British Council) will deal with the European demand for British scientific literature, Miss Esther Simpson will speak on the Society for Visiting Scientists, and Ronald Fraser (Control Commission for Germany and Austria) on Germany; information services in other European countries will also be surveyed. Further particulars of the conference can be obtained from the Association of Special Libraries and Information Bureaux, 52 Bloomsbury Street, London, W.C.1.

\section{University of/London Appointments}

THE following appointments in the University of London have been announced: Dr. S. E. Hollingworth, a senior geologist in H.M. Geological Survey, to the Yates-Goldsmid chair of geology tenable at University College, as from October 1; and Dr. Ronald Hare, of the Connaught Laboratories, University of Toronto, to the University chair of bacteriology tenable at St. Thomas's Hospital Medical School, as from October 1.

The following titles, in respect of the posts indicated, have been conferred: Mr. W. R. Spurrell, Guy's
Hospital Medical School, to be professor of physiology in the university; Dr. L. E. Bayliss, University College, to be reader in physiology in the University ; Dr. S. J. De Navasquez, Guy's Hospital Medical School, to be reader in pathology in the University; Dr. R. W. B. Pearce, Imperial College of Science and Technology, to be reader in spectroscopy in the University; Dr. R. J. V. Pulvertaft, Westminster Hospital Medical School, to be professor of clinical pathology in the University; Dr. W. D. Wright, Imperial College of Science and Technology, to be reader in colour vision in the University; Dr. C. E. Wynn-Williams, Imperial College of Science and Technology, to be reader in physics in the University.

Karel Preis (1846-1916)

ALthough not widely known outside Central Europe, Karel Preis contributed to the advance of two scien qu funded a sugar research station and a now foffows technical museum. His parents were French probably settling in Bohemia as young rofuges during the Napoleonic wars. At one time hif Aather had a wine business in Prague, where Karel was born on August 20, 1846. After studying chem. istry and other sciences at the Polytechnic, Preis was eventually made a professor there in 1868. In his small analytical laboratory he engaged upon a series of minor researches, and one of his earliest discoveries related to a double sulphide of iron and potassium, $\mathrm{K}_{2} \mathrm{~S}, \mathrm{FeS}$, which he made by heating sulphur, reduced iron and potassium carbonate together to bright redness. Ten years later (1879), together with B. Rayman, he studied the action of nitric acid on cholesterol and cholesteryl chloride, and in 1884 they prepared and examined the bromides of tin. They isolated a number of derivatives and studied the reactions of the tin halides with water, ammonia and other substances. In addition to these researches, Preis wrote a number of text. books and trained many successful technical chemists, particularly for the sugar industry. He was editor of the Chemické Listy for twenty years and of the sugar journal, Listy Cukrovarnické, for thirty-three years. Moreover, Preis was a keen naturalist and collector of insects; he wrote a monograph on Czech Hymen. optera.

\section{Announcements}

Prof. Arthur Holmes, regius professor of geology in the University of Edinburgh, has been elected a corresponding member of the Geological Society of Bolgium, in recognition of his important contributions to geological science.

Prof. H. S. RAPER, since 1923 Brackenbury professor $/ 1$ physiology and director of the Physiological Laboratories in the University of Manchester, has been appointed dean of the Medical School and professor of chemical physiology in the University. Dr. W. Schlapp, reader in experimental physiology and assistant director of the Physiological Laboratories, has been appointed to the Brackenbury chair and to the directorship of the Physiological Laboratories.

Erratuy. The ordinates of the graph accompanying the communication entitled "Effect of $p \mathrm{H}$ in the Dye Titration of Vitamin C in Certain Plant Matprials" by Dr. F. Wokes in Nature of July 27, p. 133 , should read " $100,75,50,25$ " and not " 10 , $7,5,2$ " as printed. 